\title{
Ezh2, a novel target in detection and therapy of breast cancer
}

EDITORIAL

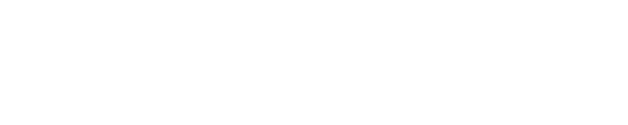

\author{
Sarah Pourakbar ${ }^{1,2}$ \\ Timothy J Pluard ${ }^{3}$ \\ Anthony D Accurso' \\ Faris Farassati ${ }^{1,3}$ \\ 'Midwest Biomedical Research \\ Foundation, Kansas City Veterans \\ Affairs Medical Center, ${ }^{2}$ University \\ of Missouri-Kansas City School \\ of Medicine, ${ }^{3}$ Saint Luke's Cancer \\ Institute, Kansas City, MO, USA
}

In 2013, 232,340 new cases of invasive breast cancer and 39,620 breast cancer deaths were estimated among US women. ${ }^{1}$ Currently, one in eight women in the US will develop breast cancer in her lifetime, and breast cancer is the second leading cause of cancer death among women. ${ }^{1}$ Despite many therapeutic advances over the last 20 years, metastatic disease remains a major cause of death for breast cancer patients, elucidating a crucial problem in the overall management of patients. ${ }^{2}$ The 5 -year survival rate for metastatic breast cancer is currently estimated as $<25 \%$. ${ }^{3,4}$

The primary molecular subtypes of breast cancer have been identified by molecular markers: luminal tumors that are estrogen receptor and progesterone receptor positive, HER-2 positive tumors, and triple-negative breast cancer (TNBC) in which all markers are negative. ${ }^{5}$ As expected, these different cancer phenotypes have varying behaviors and prognoses, with the luminal type being well differentiated and the HER-2 and TNBC types being poorly differentiated. Furthermore, TNBC, which accounts for about $20 \%$ of all breast cancers, does not benefit from currently available endocrine and HER-2-targeted therapies. Given the more aggressive disease course and poor prognosis, including higher likelihood of brain and lung metastasis, it is important to identify novel therapeutic strategies for this subtype. ${ }^{5}$

Enhancer of Zeste Homolog 2 (Ezh2), is a Histone-lysine N-methyltransferase enzyme that is encoded by the EZH2 gene. Ezh2 is a member of the polycomb group, a family of proteins that act as suppressors of transcription. ${ }^{6}$ Ezh2's suppressor function occurs via the addition of three methyl groups to Lysine 27 of histone 3, a modification leading to chromatin condensation. Ezh2 is overexpressed in a number of human malignancies, including breast cancer, and its overproduction leads to oncogenesis by decreasing the expression of tumor suppressor genes. Ezh2 is of interest as a therapeutic target in TNBC, as TNBC has been shown to overexpress this protein. ${ }^{5}$ Targeting Ezh2 might provide an alternative treatment option to cytotoxic chemotherapy, the current standard of care for TNBC patients.

Multiple studies have confirmed the overexpression of Ezh2 in TNBC, as its presence has been associated with high tumor cell proliferation and features of aggressive breast cancer, including high nuclear grade and HER-2 positivity. ${ }^{7}$ In contrast, lowgrade estrogen receptor-positive breast cancers, which generally have much better prognoses, have shown low Ezh2 expression. ${ }^{7}$ Consequently, studies have shown impaired tumor cell proliferation and metastasis after knockdown of Ezh2. ${ }^{5}$ Ezh2 overexpression has been associated with increased tumor size and disease stage, younger age of disease onset, negative hormone receptor status, and poor survival. Furthermore, overexpression of Ezh2 has been associated with poorly differentiated
Correspondence: Faris Farassat

Midwest Biomedical Research

Foundation, Kansas City Veterans

Affairs Medical Center, 480 I E Linwood

Boulevard, Kansas City, MO 64I28, USA

Tel + I 8169222858

Fax + I 816922 4712

Email ffarassati@gmail.com
OncoTargets and Therapy 2017:10 2685-2687

2685

Dovepress in 0

http://dx,doi.org/10.2147/0TT.S138777 (c) (i) (5) 2017 Pourakbar et al. This work is published and licensed by Dove Medical Press Limited. The full terms of this license are available at https://www.dovepress.com/terms.php (c) hereby accept the Terms. Non-commercial uses of the work are permitted without any further permission from Dove Medical Press Limited, provided the work is properly attributed. For permission for commercial use of this work, please see paragraphs 4.2 and 5 of our Terms (https://www.dovepress.com/terms.php). 
histologic features, particularly the TNBC phenotype, ${ }^{8}$ and thus, worse prognosis.

Not only has Ezh2 overexpression been confirmed in TNBC, but also it has been shown to be crucial in the selfrenewal of TNBC cells. Studies have established the presence of a subpopulation of cells within a tumor that have the ability to self-renew and initiate tumor formation, whereas the majority of tumor cells are unable to self-renew. These cells, called as cancer stem cells (CSCs), are long lived and have been shown to be resistant to chemotherapy, and promote tumor reoccurrence and metastasis. ${ }^{9}$ CSCs are present in TNBC, with Ezh2 having been identified as playing an important role in the self-renewal of breast CSCs. ${ }^{9}$

Increased expression of Ezh2 has been shown to be associated with transformation of breast epithelial cells to neoplasia, ${ }^{10}$ including atypical ductal hyperplasia, ductal carcinoma in situ, and inflammatory breast cancer (IBC). ${ }^{11}$ In morphologically normal breast tissue, Ezh2 is a molecular marker for precancerous states. ${ }^{12}$ Ezh2 has also been found to be a marker for aggressive breast cancer, as increased expression has been associated with disease progression. Ezh2 has been shown to repress the expression of E-Cadherin, ${ }^{13}$ enhance p38-kinase signaling, ${ }^{14}$ and prevent DNA repair, ${ }^{15}$ and these are likely the main mechanisms contributing to tumorigenesis and disease progression.

In addition to contributing to tumorigenesis, Ezh2 also appears to increase the risk of distant metastasis in patients with familial early-stage breast cancer. ${ }^{16}$ Ezh2 knockdown was shown to inhibit the migration and invasion of IBC cells. Additionally, Ezh2 knockdown suppressed the angiogenesis and tumor growth of IBC cells in vivo. ${ }^{17}$ Analysis of a cohort of 400 human tumors found Ezh2 to be overexpressed in clinically challenging types of breast cancer, such as basallike, triple-negative disease, and HER-2-enriched tumors. ${ }^{18}$

As the work on developing a targeted inhibitor of Ezh2 continues, our team is investigating the effects of eradication of Ezh2+ cells in vivo. Preliminary data in animal models appear very promising (F Farassati, unpublished data April, 2017), supporting our efforts to elucidate the future of Ezh2 as a novel target for therapy.

\section{Disclosure}

The authors report no conflicts of interest in this work.

\section{References}

1. DeSantis C, Ma J, Bryan L, Jemal A. Breast cancer statistics. 2013. CA Cancer J Clin. 2014;64(1):52-62.

2. Martins D, Beca F, Schmitt F. Metastatic breast cancer: mechanisms and opportunities for cytology. Cytopathology. 2014;25(4):225-230.

3. Siegel R, Naishadham D, Jemal A. Cancer statistics. 2013. CA Cancer J Clin. 2013;63(1):11-30.

4. Beaumont $\mathrm{T}$, Leadbeater M. Treatment and care of patients with metastatic breast cancer. Nurs Stand. 2011;25(40):49-56.

5. Wang X, Hu B, Shen H, et al. Clinical and prognostic relevance of EZH2 in breast cancer: a meta-analysis. Biomed Pharmacother. 2015; 75:218-225.

6. Inari H, Suganuma N, Kawachi K, et al. Expression of enhancer of zeste homolog 2 correlates with survival outcome in patients with metastatic breast cancer: exploratory study using primary and paired metastatic lesions. BMC Cancer. 2017;17(1):160

7. Guo S, Li X, Rohr J, et al. EZH2 overexpression in different immunophenotypes of breast carcinoma and association with clinicopathologic features. Diagn Pathol. 2016;11:41

8. Jang $\mathrm{SH}$, Lee JE, Oh MH, et al. High EZH2 protein expression is associated with poor overall survival in patients with luminal a breast cancer. J Breast Cancer. 2016;19(1):53-60.

9. Lawrence CL, Baldwin AS. Non-canonical EZH2 transcriptionally activates RelB in triple negative breast cancer. PLoS One. 2016;11(10): e0165005.

10. Kleer CG, Cao Q, Varambally $\mathrm{S}$, et al. EZH2 is a marker of aggressive breast cancer and promotes neoplastic transformation of breast epithelial cells. Proc Natl Acad Sci U S A. 2003;100(20):11606-11611.

11. Collett K, Eide GE, Arnes J, et al. Expression of enhancer of zeste homologue 2 is significantly associated with increased tumor cell proliferation and is a marker of aggressive breast cancer. Clin Cancer Res. 2006;12(4):1168-1174.

12. Ding L, Erdmann C, Chinnaiyan AM, Merajver SD, Kleer CG. Identification of EZH2 as a molecular marker for a precancerous state in morphologically normal breast tissues. Cancer Res. 2006;66(8):4095-4099.

13. Cao Q, Yu J, Dhanasekaran SM, et al. Repression of E-cadherin by the polycomb group protein EZH2 in cancer. Oncogene. 2008;27(58): 7274-7284.

14. Moore HM, Gonzalez ME, Toy KA, et al. EZH2 inhibition decreases p38 signaling and suppresses breast cancer motility and metastasis. Breast Cancer Res Treat. 2013;138(3):741-752.

15. Zeidler M, Kleer CG. The Polycomb group protein Enhancer of Zeste 2: its links to DNA repair and breast cancer. J Mol Histol. 2006; 37(5-7):219-223.

16. Alford SH, Toy K, Merajver SD, Kleer CG. Increased risk for distant metastasis in patients with familial early-stage breast cancer and high EZH2 expression. Breast Cancer Res Treat. 2012;132(2):429-437.

17. Mu Z, Li H, Fernandez SV, Alpaugh KR, Zhang R, Cristofanilli M. EZH2 knockdown suppresses the growth and invasion of human inflammatory breast cancer cells. J Exp Clin Cancer Res. 2013;32(1):70.

18. Holm K, Grabau D, Lövgren K, et al. Global H3K27 trimethylation and EZH2 abundance in breast tumor subtypes. Mol Oncol. 2012;6(5):494-506. 
Dove Medical Press encourages responsible, free and frank academic debate. The content of the OncoTargets and Therapy 'Editorial' section does not necessarily represent the views of Dove Medical Press, its officers, agents, employees, related entities or the OncoTargets and Therapy editors. While all reasonable steps have been taken to confirm the content of each Editorial, Dove Medical Press accepts no liability in respect of the content of any Editorial, nor is it responsible for the content and accuracy of any Editorial.

OncoTargets and Therapy

\section{Publish your work in this journal}

OncoTargets and Therapy is an international, peer-reviewed, open access journal focusing on the pathological basis of all cancers, potential targets for therapy and treatment protocols employed to improve the management of cancer patients. The journal also focuses on the impact of management programs and new therapeutic agents and protocols on The manuscript management system is completely online and includes a very quick and fair peer-review system, which is all easy to use. Visit http://www.dovepress.com/testimonials.php to read real quotes from published authors.

Submit your manuscript here: http://www.dovepress.com/oncotargets-and-therapy-journal 